\title{
Stadniny konne jako potencjał regionalizmu w rozwoju turystyki Warmii i Mazur
}

\section{Horse studs - the potential of regionalism for tourism development of Warmia and Masuria}

\begin{abstract}
Streszczenie
W artykule przedstawiony został aspekt regionalizmu, jakim są stadniny koni na Warmii i Mazurach wraz z rolą, jaką odgrywają w rozwoju turystyki. Na przykładzie jednych z najstarszych i najbardziej reprezentacyjnych ośrodków, znajdujących się na wyjątkowo charakterystycznej dla omawianego obszaru trasie turystycznej - Szlaku Konnym im. Marion Dönhoff, przeanalizowano wpływ ich obecności na rozwój cennych przyrodniczo terenów.
\end{abstract}

Słowa kluczowe: Mazury, Warmia, stadniny koni, turystyka, regionalizm, rozwój turystyki

Abstract

The article presents an aspect of regionalism in the occurence of multiple horse studs in the region of Warmia and Masuria along with the role they play in the development of tourism. The impact of their presence on the development of environmentally valuable areas has been analysed on the examples of ones of the oldest and representative facilities placed on the - Marion Dönhoff bridle path, peculiar to the region type of trail.

Keywords: Masuria, Warmia, horse studs, horse farms, tourism, regionalism, tourism development 


\section{WSTĘP}

Wraz z rozwojem turystyki można zaobserwować, że otoczenie przyrodnicze jest aspektem coraz bardziej pożądanym w kontekście rekreacji i stanowi szczególnie atrakcyjną dla człowieka przestrzeń. Rosnące zainteresowanie problematyką środowiska naturalnego wśród ludzi skutkowało ustanowieniem wielu nowych form ochrony przyrody na terenie Polski. Działania tego rodzaju prowadzone są na wyjątkowo dużą skalę i mają szczególne znaczenie dla regionu Warmii i Mazur, cechującego się wysokimi i zarazem unikatowymi walorami krajobrazu, wód oraz przestrzeni zielonych. Duże zróżnicowanie przyrodnicze świadczy dodatkowo o tym, że Kraina Tysiąca Jezior ma przede wszystkim charakter rekreacyjny i stanowi tym samym jeden z najchętniej wybieranych kierunków turystycznych. Stąd też, biorąc pod uwagę walory naturalne cennych przyrodniczo obszarów Warmii i Mazur oraz ich w dużej części pozostawiony bez ingerencji człowieka krajobraz, jednym z kluczowych kierunków rozwoju terenów wydaje się turystyka w duchu regionalizmu, zakładająca promowanie tego, co lokalne i autentyczne, wraz z jednoczesną ochroną zastanego dziedzictwa i bogactwa natury. Co więcej, nie sposób nie dostrzec przy tym niezwykłego powiązania istnienia stadnin koni z historią regionu, o czym świadczy po pierwsze ulokowanie na tym obszarze ponad stu stadnin (Galopuje.pl, 2021), po drugie rozwój turystyki konnej, a po trzecie fakt, że to właśnie tym terenom swoje powstanie zawdzięcza rodzima rasa - konik polski.

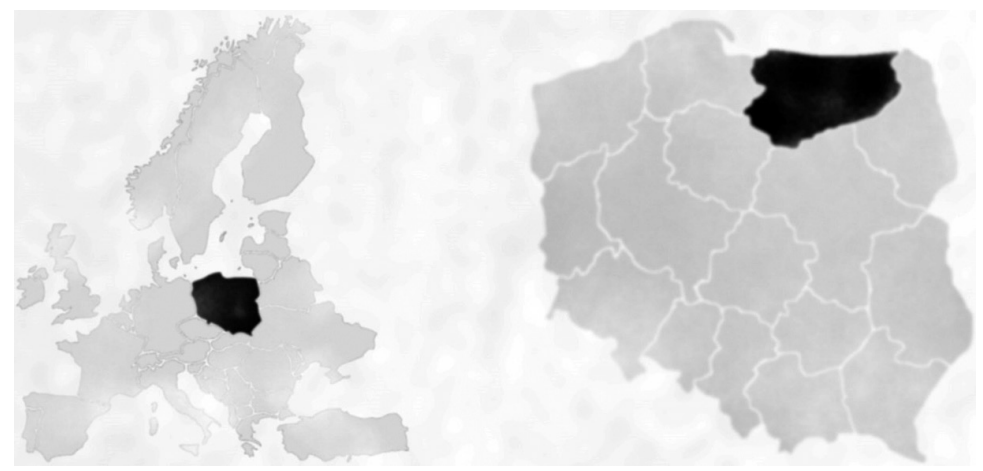

II. 1. Położenie województwa warmińsko-mazurskiego w Europie i w Polsce. Oprac. własne

\section{CEL, ZAKRES, METODA}

Do zobrazowania, jak głęboko jazda konna tkwi w tradycji regionu, posłużono się przykładem działania z zakresu turystyki, a konkretnie - jednego z prawidłowo wytyczonych szlaków konnych na Warmii i Mazurach. Jest nim szlak imienia niemieckiej hrabiny i dziennikarki Marion Dönhoff, którego 250-kilometrowa trasa przebiega z Olsztyna do Sztynortu, głównie 
przez lasy (11 nadleśnictw i 17 gmin) i w całości w obrębie Warmii i Mazur (Gełdon, 2019), co oznacza przejażdżkę wśród malowniczych krajobrazów jezior oraz zieleni, stanowiącej atut terenów północnej Polski. Wielbiciele spędzania czasu w siodle, korzystając z zalet naturalnego ukształtowania terenu, mają możliwość podążenia dawną trasą dziennikarki, uciekającej w 1945 roku przed Armią Czerwoną do Niemiec. Dodatkowo szlak ten prezentuje się na tyle atrakcyjnie, że - z użyciem specjalnie przygotowanych mobilnych map dostępnych na stronie Lasów Państwowych - można jednocześnie skorzystać z bogatej oferty gastronomicznej oraz noclegowej, zarówno dla jeźdźców, jak i koni, znajdujących się na jego trasie stadnin. Połączone ze sobą ośrodki tworzą jednolitą sieć, organizując w ten sposób turystykę konną regionu. Szlak, ze względu na swą długość i stosunkowo długi czas do spędzenia w siodle, polecany jest szczególnie średniozaawansowanym i zaawansowanym jeźdźcom, a tym mniej doświadczonym zaleca się z kolei przejechanie krótszych odcinków, np. z instruktorem.

Opisana forma rekreacji z wykorzystaniem lokalnej tradycji oraz z poszanowaniem walorów przyrodniczych regionu narodziła się w analizowanym obszarze dzięki pomysłowi i inicjatywie Ewy i Tadeusza Piórkowskich (specjalistów w dziedzinie nauki jazdy konnej) oraz dzięki redaktorce gazety „Die Zeit”, która jako pierwsza zapragnęła samotnie przejechać trasę, upamiętniając tym samym setne urodziny Dönhoff (Gruchała, 2019).

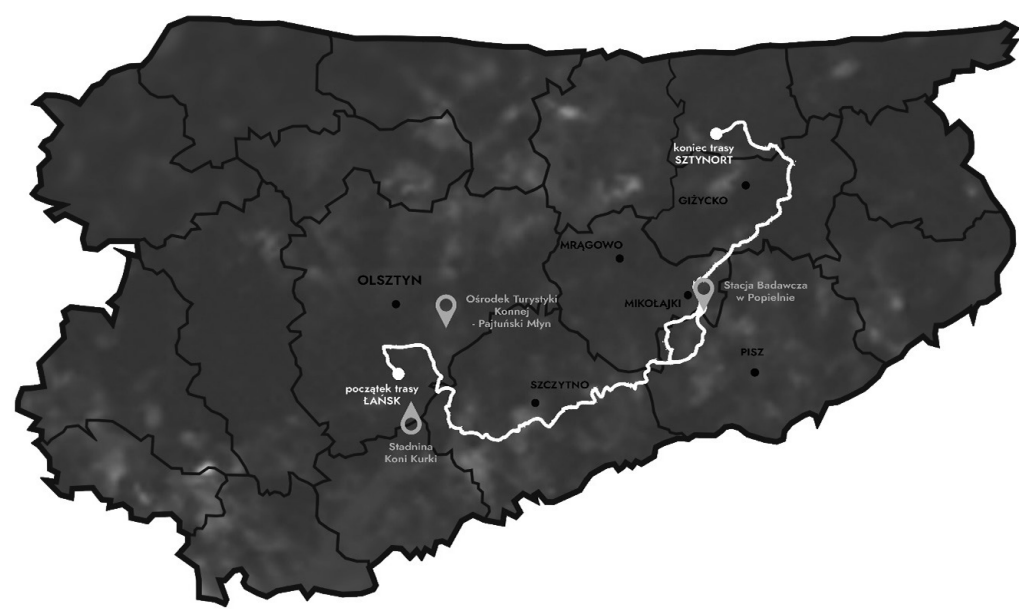

II. 2. Przebieg trasy szlaku konnego im. Marion Dönhoff w województwie warmińsko-mazurskim z oznaczeniem lokalizacji analizowanych stadnin. Oprac. własne na podst. (Adamska, Łopatko-Pomianek, 2015)

W związku z tym za cel naukowy obrano wykazanie związku między obecnością stadnin koni na terenie Warmii i Mazur a regionalizmem i rolą, jaką odgrywają one w rozwoju turystyki na tych cennych przyrodniczo terenach. Analizy tego aspektu przestrzennego zostały przeprowadzone na przykładach trzech z najstarszych i najbardziej reprezentacyjnych 
ośrodków w regionie, znajdujących się na trasie szlaku konnego im. Marion Dönhoff: stadnin w Popielnie, w Kurkach oraz ośrodka turystyki konnej Pajtuński Młyn. Zakres miejscowy obejmuje zatem obszar zdeterminowany bezpośrednio przez lokalizację analizowanych stadnin. Czasowy zakres analiz, wyznaczony przez daty powstania omawianych ośrodków, obejmuje okres od 1945 do 2021 roku.

Początkowy etap badań oparty był na wizji lokalnej, podczas której wykorzystano także metodę obserwacyjną i wykonano dokumentację fotograficzną analizowanego terenu. Dzięki metodzie badań fokusowych zebrano materiał w postaci informacji pozyskanych zarówno w rozmowach z mieszkańcami Warmii i Mazur, jak i od przebywających tam turystów. Analiza krytyczna literatury i źródeł internetowych umożliwiła zaś poszerzenie zdobytej wiedzy oraz sformułowanie problemu badawczego.

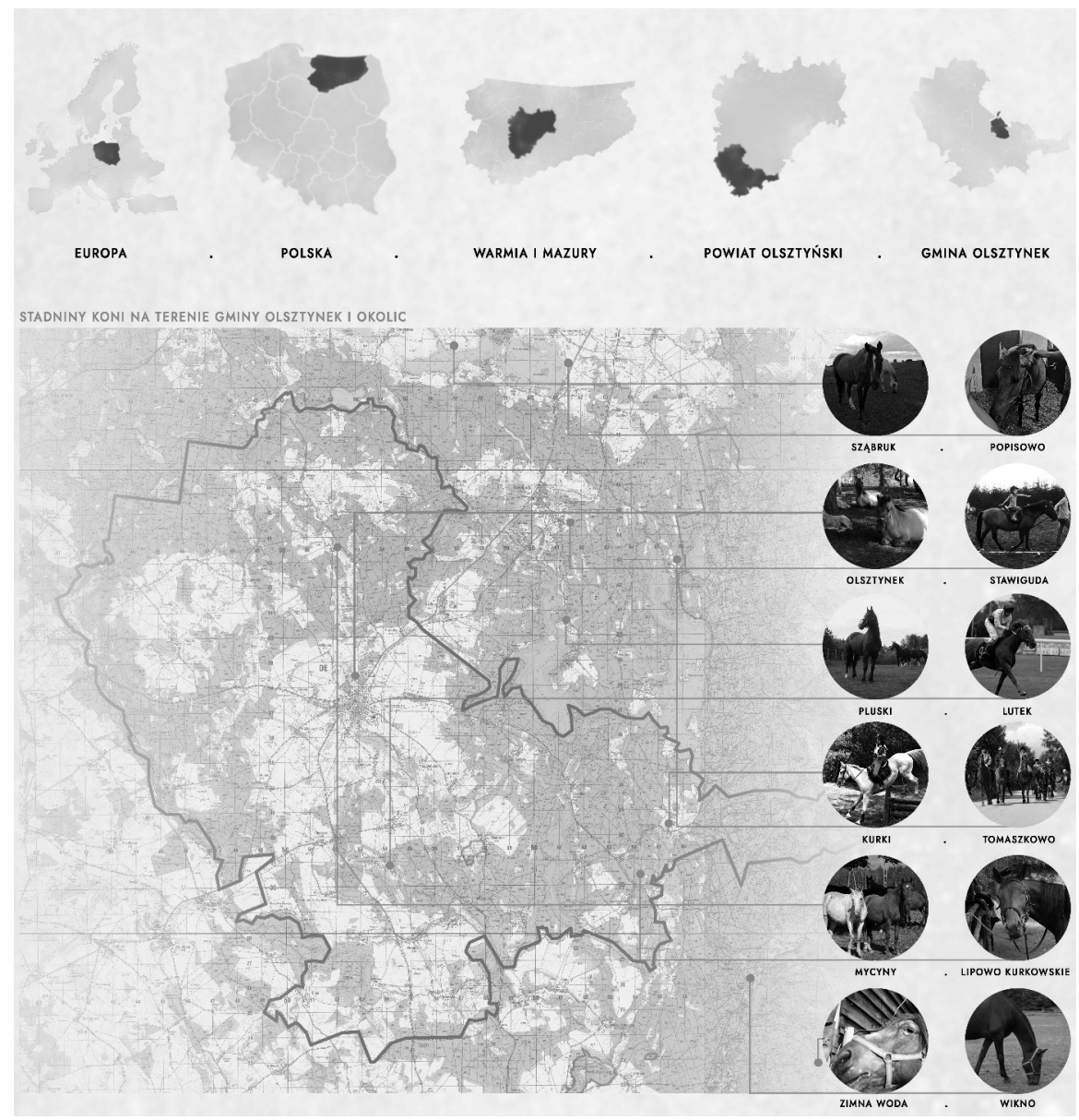

II. 3. Analiza stadnin koni na terenie badań in situ - gmina Olsztynek i okolice. Oprac. własne 


\section{UWARUNKOWANIA PRZYRODNICZE WARMII I MAZUR}

Tereny Warmii i Mazur należą do jednych z najcenniejszych pod względem przyrodniczym terenów Polski. Cechuje je bogactwo natury - pierwotnej, niemalże nienaruszonej i nietkniętej przez człowieka. Nie bez przyczyny jest to więc kraina przez wielu kojarzona z miejscem wytchnienia. Otoczona przez bezkresne przestrzenie lasów wraz z ogromną liczbą jezior (źródła podają, że jest ich aż 2600) (Dziennik.pl, 2017) oraz niezwykłym krajobrazem, kształtowanym przez wieki w wyniku działań lądolodu, w rzeczy samej stanowi jedyną w swoim rodzaju oazę spokoju.
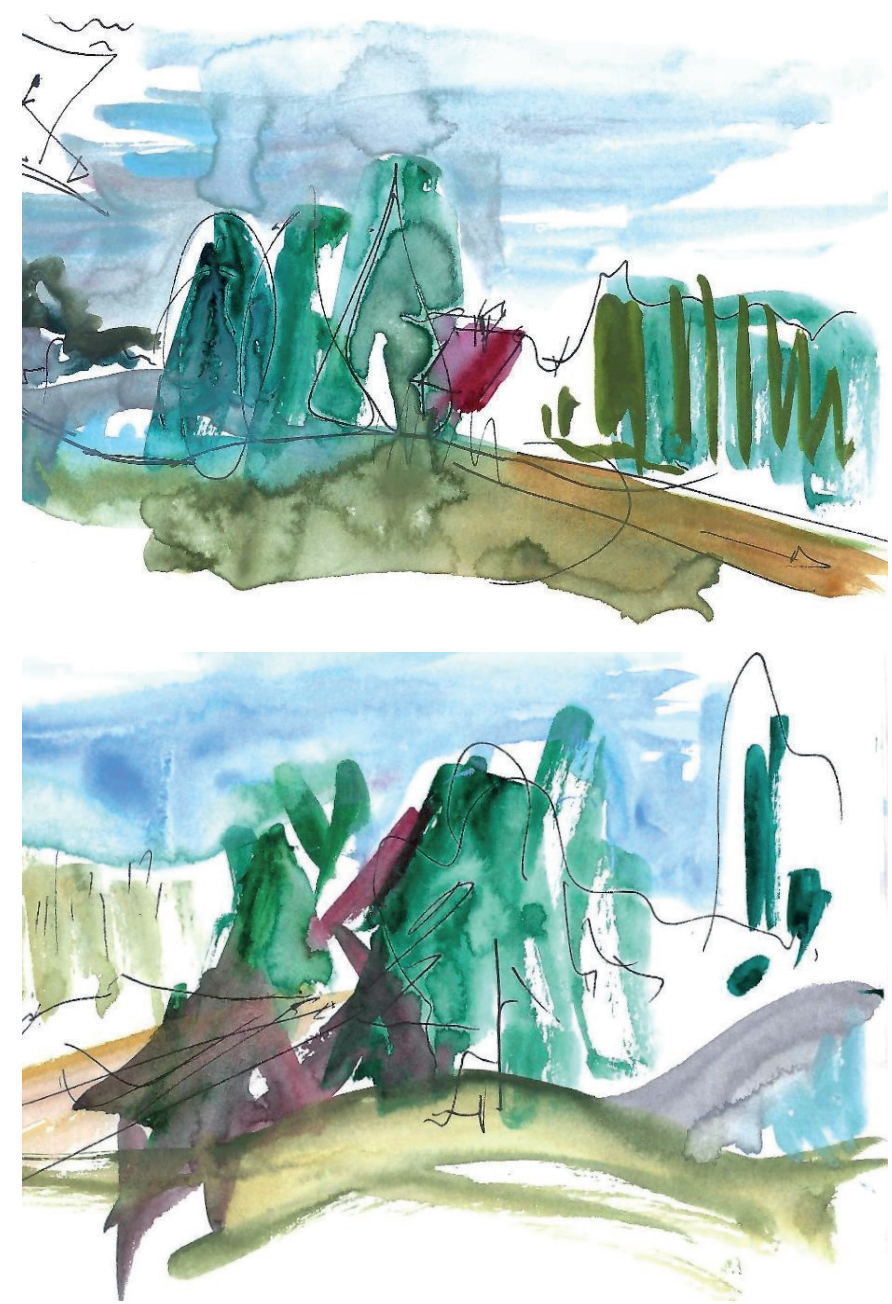

II. 4-5. Wrażeniowe szkice akwarelowe z obszaru badań in situ. Rys. autor 

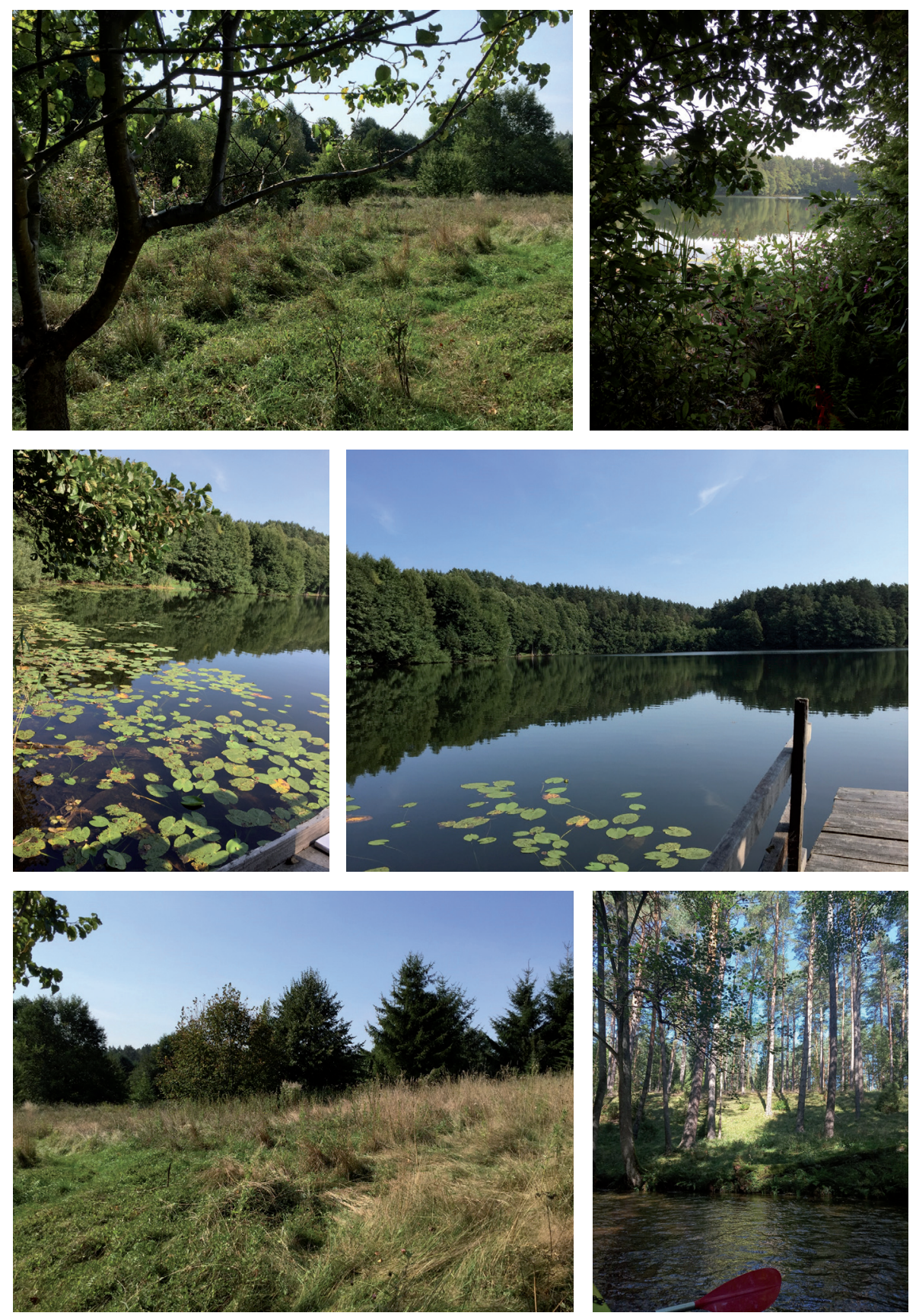

II. 6-11. Dokumentacja fotograficzna z obszaru badań in situ - wsie Świerkocin i Swaderki. Fot. autor i K. Migacz 
Dowodem na to jest niewątpliwie fakt, że opisywane tereny zostały włączone do regionu o nazwie Zielone Płuca Polski, wydzielonego w 1988 roku w celu stworzenia „podstaw organizacyjnych i programowych dla kompleksowej ochrony racjonalnego kształtowania środowiska" (Różański i in., 2012: 42). Całościowo obszar zajmuje poczesne miejsce na turystycznej i krajobrazowej mapie Polski ze względu na nagromadzenie licznych zbiorników czy cieków wodnych, a także ogromne powierzchnie lasów, będących siedliskiem rozmaitej, w dużej części chronionej flory i fauny. Elementy te stanowią tworzywo wielofunkcyjne - sprzyjające rekreacji, turystyce, produkcji drewna, zachowaniu bazy genetycznej ekosystemów i ochronie przyrody. Jeśli chodzi o tę ostatnią funkcję, warto dodać, że Warmia i Mazury znalazły się na liście terenów chronionych Europejskiej Sieci Ekologicznej Natura 2000, która służy ochronie walorów przyrodniczych danego miejsca i „zagrożonych składników różnorodności biologicznej kontynentu europejskiego" (Różański i in., 2012: 47).

Jak można się dowiedzieć z dokumentu M. Biczkowskiego i P. Brodowskiego, zatytułowanego Uwarunkowania rozwoju oraz stan zagospodarowania agroturystycznego na obszarze dorzecza Drwęcy, zasadnicze zalecenie dla planowania przestrzennego gmin województwa warmińsko-mazurskiego to zrównoważony rozwój gospodarczy, którego podstawę ma stanowić m.in. wykorzystanie wysokich walorów przyrodniczo-krajobrazowo-kulturowych i turystyczno-wypoczynkowych obszaru (Biczkowski, Brodowski, 2007). Autor podkreśla, że kluczowa dla rozwoju jest agroturystyka, która nie wymaga większych inwestycji czy poświęcania terenów pod zabudowę, pozwala na ochronę walorów przyrodniczych, a do tego może rozsławić region w Polsce i za granicą.

Krótko mówiąc, charakter i uwarunkowania Warmii i Mazur silnie łączą się z regionalizmem, wyznaczającym strategię rozwoju obszaru. Na analizowanym terenie odgrywa on ogromną rolę jako motor korzystnych przemian, a zarazem gwarant zachowania tego, co naturalne. Jego częścią zaś są lokalna historia oraz występujące w regionie od wieków gatunki zwierząt, w tym konie.

\section{ROLA STADNIN W ROZWOJU TURYSTYKI I ICH ZWIAZZKI Z REGIONALIZMEM}

Obszar Warmii i Mazur cieszy się długą tradycją konną, o czym świadczy ponad sto stadnin, stajni, klubów jeździeckich czy różnego rodzaju hodowli (rezerwatowa, stajenna i bezstajenna) rozlokowanych w obrębie województwa, które, jak się okazuje, zajmuje pod względem ich liczebności pierwsze miejsce w Polsce (Galopuje.pl, 2021). Ich oferta jest bardzo szeroka i obejmuje szereg aktywności - od nauki jazdy konnej, przejażdżek, rehabilitacji w formie hipoterapii, przez treningi sportowe dla profesjonalistów, woltyżerkę i zawody, po rozmaite możliwości pojenia koni w gospodarstwach wiejskich czy oglądanie ich na pastwiskach i pokazach (Targońska, 2016). Turysta ma możliwość samodzielnej jazdy zarówno na typowych dla całego kraju wierzchowcach, jak i na szczególnie charakterystycznych dla 
regionu przedstawicielach tzw. polskich ras prymitywnych, do których należy przede wszystkim jedyny zachowany potomek tarpanów, zamieszkujących tereny m.in. dawnych Prus Wschodnich, czyli konik polski.

\subsection{KRYTERIA DOBORU PRZYKŁADÓW}

Badania oparto na analizie trzech wybranych obiektów o funkcji stadnin koni, powstałych w latach 1945-2021 oraz znajdujących się bezpośrednio na trasie szlaku konnego im. Marion Dönhoff, biegnącego w południowej części województwa warmińsko-mazurskiego i mieszczącego się w całości na terenie Warmii i Mazur. Kryterium doboru przykładów stanowił także wyróżnik w postaci historii stadnin i okoliczności ich powstania, hodowanej rasy koni, jakości oferowanego programu oraz jego związku z regionalizmem.

\subsection{CASE STUDY}

\subsubsection{POPIELNO - HODOWLA REZERWATOWA KONIKA POLSKIEGO JAKO PRZYKŁAD OCHRONY PRZYRODY W DUCHU REGIONALIZMU}

Główny ośrodek na Warmii i Mazurach zajmujący się hodowlą konika polskiego - gatunku wyjątkowo związanego z omawianym regionem - to Stacja Badawcza Rolnictwa Ekologicznego i Hodowli Zachowawczej Zwierząt PAN w Popielnie, która od 1949 roku prowadzi jego stajenny chów (PAN Popielno, 2021), a od roku 1955 - po przejęciu przez Polską Akademię Nauk - także hodowlę rezerwatową. W 1939 roku, od momentu założenia przez prof. T. Vetulaniego rezerwatu w Puszczy Białowieskiej, koniki polskie lokowano w różnych ośrodkach w kraju. Popielno stanowiło wówczas jeden z nich, a dziś jest to szczególnie wyjątkowe dla Warmii i Mazur miejsce, ponieważ umożliwiło ostatecznie zebranie razem całego materiału genetycznego, tworząc główne centrum badawcze i hodowlane rodzimej rasy regionu (Jaworski, Tomczyk-Wrona, 2009). Założenie urbanistyczne obejmuje kilka obiektów, do których należy m.in. Muzeum Przyrodnicze PAN, rozmieszczonych w pozornie symetrycznym ułożeniu, równoległym do wschodniej granicy działki. Dodatkowo zabudowa rozchodzi się liniowo w prostopadłych kierunkach, począwszy od wjazdu na teren hodowli, co wpływa na jej bardziej rozproszony układ.

Historia bytowania konika polskiego na terenie Warmii i Mazur jest bardzo długa - trwa już od średniowiecza. Właśnie dawne Prusy Wschodnie to miejsce jego pochodzenia. Jako jedyna rodzima rasa koni wywodzi się bezpośrednio od dzikich koni, które żyły w miejscach słabo zaludnionych, na łąkach i w lasach, dzięki czemu koniki polskie nabyły wyjątkową odporność i są przystosowane do życia w srogich warunkach atmosferycznych. Pozwala to na utrzymywanie rasy przez cały rok w hodowli bezstajennej (w Polsce dotyczy to aż 54\% przypadków). W ośrodku w Popielnie koniki przebywają w naturalnym środowisku, a ingerencje człowieka ograniczają się do sytuacji zagrożenia życia czy do dokarmiania sianem zimą. 

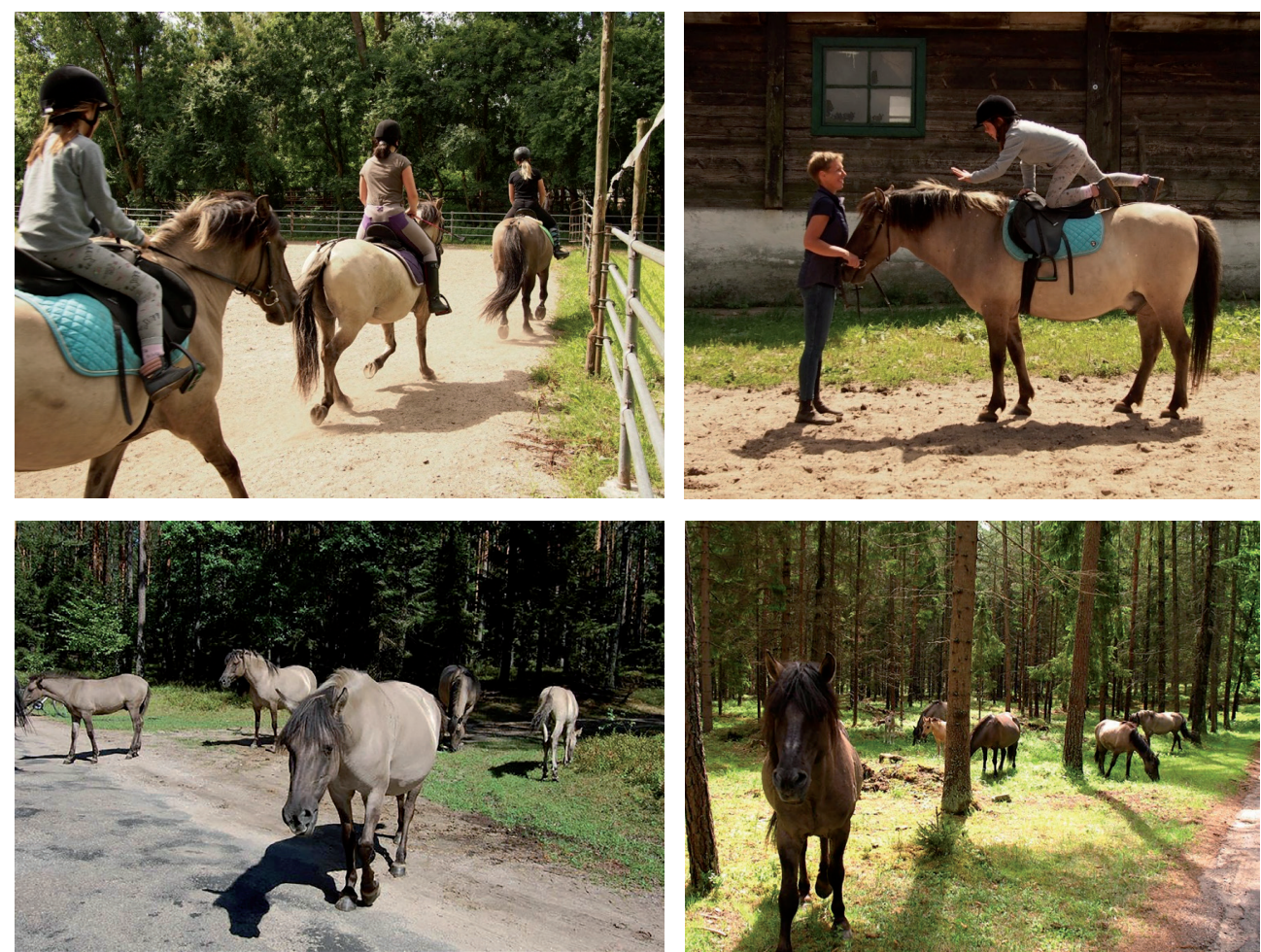

II. 12-15. Koniki polskie w stacji badawczej w Popielnie (PAN Popielno, 2021; Bezmapy.pl, 2013 (https://architektura.muratorplus.pl/polski-krajobraz/galeria.html?hr=12\&tp=0\&v=13452)

Dzięki temu turyści mogą spotkać konie podczas spaceru po lesie, a organizowane sporadycznie przez ośrodek pokazy walk ogierów czy pokazy źrebiąt w ich ekosystemie stanowią raczej unikalną na skalę kraju atrakcję (Targońska, 2016). Nie bez powodu także potomek tarpana nazywany jest „koniem stref lesistych” - środowisko to jest miejscem jego życia oraz źródła pokarmu. Żywiąc się gatunkami roślin często omijanymi przez inne zwierzęta, bierze udział w kształtowaniu bioróżnorodności flory, a pasąc się niczym „żywa kosiarka” ogranicza nadmierną sukcesję drzew i krzewów na terenach rezerwatów (Bezmapy.pl, 2013). Stanowi to dowód na udział koników polskich w ochronie przyrody, a przy tej okazji należy wspomnieć, że mają one też wyjątkowo przyjazne usposobienie, dzięki czemu idealnie nadają się do przeprowadzania z nimi hipoterapii (Jaworski, Jastrzębska, Górecka-Bruzda, 2018). Hodowla konika polskiego ma więc na celu, szczególnie w Popielnie, jednoczesne wykorzystanie jego zalet, dlatego zapewnia mu się naturalne, dogodne warunki bytowania. Wszystkie te działania podejmowane na rzecz zachowania rodzimej rasy Warmii i Mazur stanowią zarazem kontynuację tradycji tego regionu. 


\subsubsection{STADNINA KONI W KURKACH - HISTORIA PASJONATÓW KONI I ICH WKŁAD W ROZWÓJ NOWEJ DYSCYPLINY JAZDY KONNEJ W KRAJU}

W kolejnym z wybranych do analizy ośrodków znajdujących się na trasie szlaku konnego im. Marion Dönhoff od 1985 roku prowadzona jest hodowla koni rasy małopolskiej. Zajmuje się tym rodzina, która zamieszkała na Mazurach rok wcześniej. Zgodnie z barwnym opisem historii stadniny (Klaybor-Romańska, b.r.) jej założycielka była członkiem Klubu Jeździeckiego Uniwersytetu Warszawskiego w Zakładzie Treningowym Koni w Wólce Węglowej pod Warszawą. Wraz z mężem, po zdobyciu uprawnień instruktorskich do jazdy konnej w 1995 roku, postanowili spełnić swoje marzenie i mając wydzierżawione 3 konie, założyli szkółkę jeździecką na terenie należącego do nich gospodarstwa w Kurkach. Właścicielka zainteresowała się niespotykaną do 2011 roku w Polsce dyscypliną jeździecką TREC (z fr. Wszechstronny Konkurs Konia Turystycznego) - sprawdzającą umiejętności zarówno jeźdźca, jak i konia oraz wymagającą bezpiecznej jazdy w terenie. Już w 2015 roku udało jej się zorganizować w stadninie Kurki pierwsze na Warmii i Mazurach szkolenie dla sędziów i organizatorów TREC Polskiego Towarzystwa Turystyczno-Krajoznawczego (PTTK). Przyczyniła się do popularyzacji tej
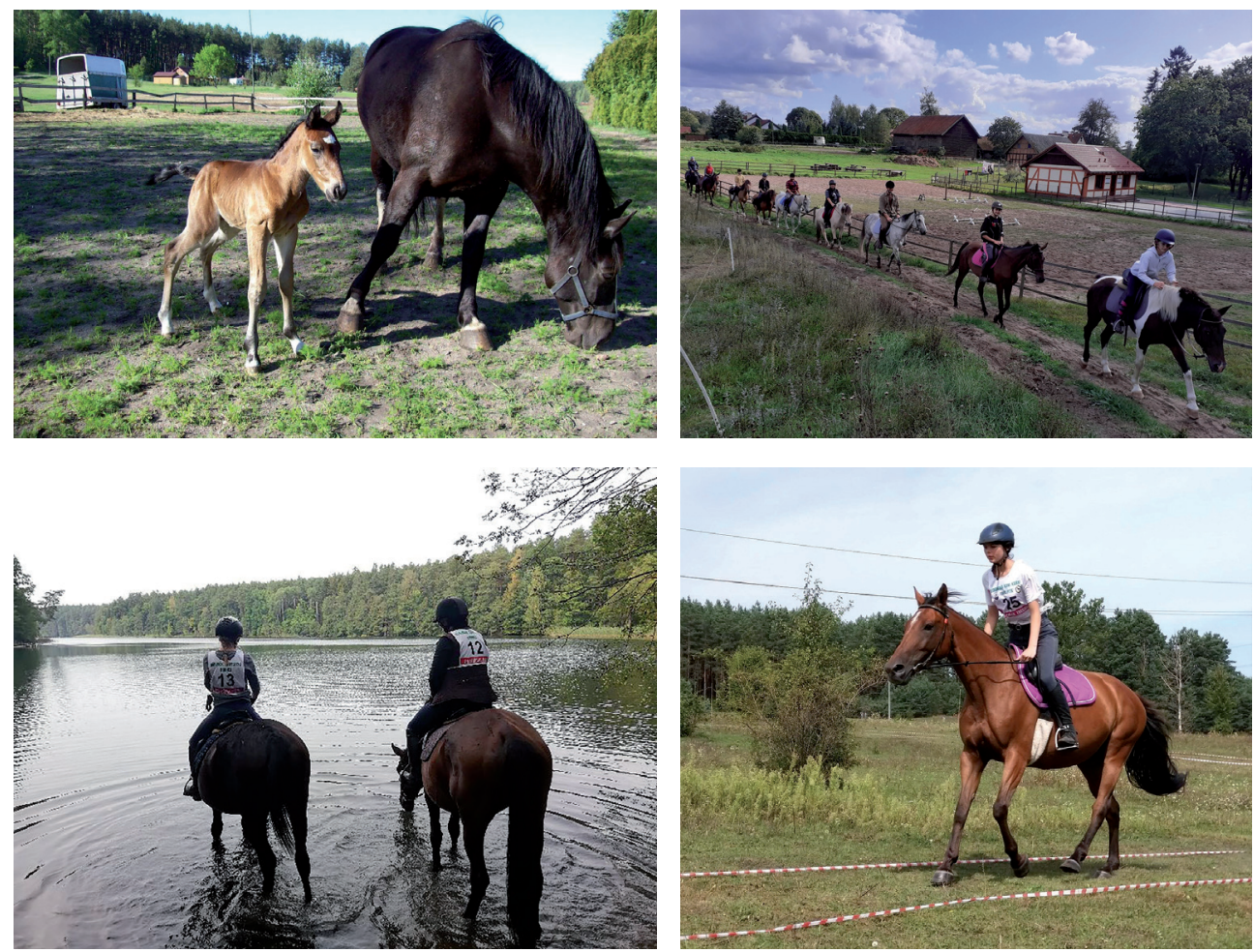

II. 16-19. Konie, rajd konny, zawody TREC PTTK 2019 w Stadninie Koni Kurki

(https://www.facebook.com/StadninaKoniKurkiTRECPTTK/photos/?ref=page_internal) 
dyscypliny na analizowanym terenie, a jako że TREC idealnie wpisuje się w turystyczno-przyrodniczy charakter okolic, jest to zarazem przykład rozpowszechniania regionalizmu w turystyce. Właścicielom dotychczas udało się zorganizować m.in. pierwsze pełne zawody TREC oraz Kurs Przodowników Turystyki Jeździeckiej PTTK. Charakter urbanistyczny założenia tworzą budynki należące do stadniny oraz dom gospodarzy, rozlokowane w sposób zwarty przy wjeździe na działkę, zaś do umieszczonej w jej głębi ujeżdżalni koni prowadzi diagonalnie biegnąca ścieżka. Granice terenu wyznaczone są także barierą lasu oraz drogi dojazdowej.

\subsubsection{OŚRODEK TURYSTYKI KONNEJ PAJTUŃSKI MŁYN, CZYLI PRZYKŁAD TRADYCJI RAJDÓW KONNYCH}

Ośrodek turystyki konnej Pajtuński Młyn - podobnie jak poprzednia stadnina - stanowi część powiatu olsztyńskiego. Jego specjalnością są rajdy i obozy konne dla ludzi w każdym wieku. Zajmuje się szkoleniami jeździeckimi i przeprowadzaniem zawodów na swoim terenie, ale jest też związany z dyscypliną TREC, przyczyniając się tym samym do promowania bezpiecznej jazdy. Historia posiadłości sięga aż XIV wieku - w 1374 roku istniał tam już młyn wodny. W 2012 roku właścicielowi udało się zakończyć remont i rozbudowę zabytkowej stajni, co umożliwiło przyjęcie pod dach ponad dwudziestu koni. Aktualnie działające
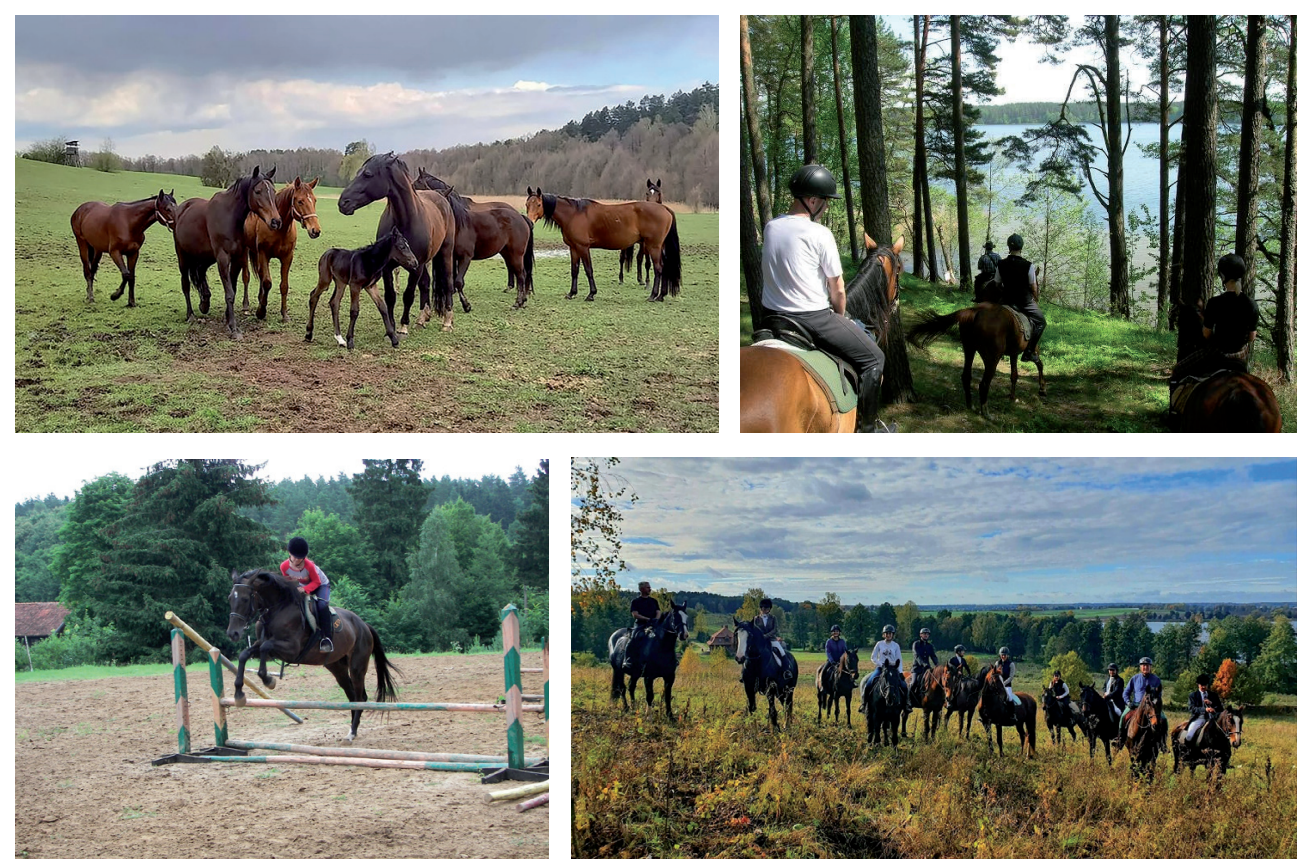

II. 20-23. Konie, oferta sportu, rekreacji i turystyki konnej w ośrodku turystyki konnej Pajtuński Młyn (https://www.facebook.com/PajtunskiMlyn/photos/?ref=page_internal) 
gospodarstwo agroturystyczne oferuje różne formy aktywnego wypoczynku, jak np. „wczasy w siodle" (Pajtuński Młyn, b.r.), a obejmuje również dom nad rzeką z pokojami do wynajęcia, który - wraz ze stodołą i pozostałymi obiektami - stanowi całość zwartej zabudowy działki. Zagospodarowanie przestrzenne dopełnia dodatkowo powierzchnia 30 ha ziemi, potęgując tym samym efekt skupienia budynków w jednym miejscu południowej części dużego terenu.

Wszystko to daje zatem wrażenie spójności z tradycją regionu i przy tym maksymalnego wykorzystania jego naturalnych zasobów w postaci środowiska przyrodniczego. Stadniny kształtują turystykę regionu i służą nie tylko działaniu w duchu regionalizmu, ale także poszanowania przyrody, poprzez dbanie o lokalnie i od dawna występujące na terenie województwa gatunki zwierząt.

\subsection{DYSKUSJA}

Przedstawione w przykładach stadniny mają wiele cech wspólnych, a jedną z nich jest niewątpliwie lokalizacja na trasie szlaku konnego im. Marion Dönhoff. Program i ofertę wszystkich tych obiektów charakteryzuje podobne podejście do turystyki, skupiające się na kontynuacji tradycji. W wypadku stadniny w Kurkach i ośrodka turystyki konnej Pajtuński Młyn przejawia się ono w przeznaczeniu przestrzeni szkoleniowych dla zainteresowanych zarówno zawodowym, jak i amatorskim jeździectwem. Z kolei stacja badawcza w Popielnie stawia na utrzymanie unikalnej rasy rodzimej regionu, gromadząc osobniki na swoim terenie. Analizowane obiekty odróżniają zaś charakter oferowanych usług oraz rasa, liczba i przeznaczenie hodowanych koni. Stadnina w Popielnie pozwala odwiedzającym jedynie na rekreacyjną jazdę, podczas gdy w stadninie w Kurkach czy w ośrodku Pajtuński Młyn jest ona możliwa także w ramach treningów, zawodów oraz rajdów konnych. Wszystkie te miejsca przyczyniają się wszakże do propagowania regionalnych zasobów i tradycji.

\section{PODSUMOWANIE}

Dzięki długiej tradycji konnej terenów Warmii i Mazur istniejące tam liczne stadniny odgrywają kluczową rolę w kształtowaniu charakteru Krainy Tysiąca Jezior, urastając tym samym do rangi wizytówki promującej w regionie to, co naturalne, lokalne i stałe od wieków. Ich zagospodarowanie przestrzenne obejmuje zwykle kilka obiektów, rozmieszczonych w pobliżu wjazdu na teren stadniny. Pozostawiony w ten sposób duży, niezabudowany obszar w głębi działki - na Warmii i Mazurach graniczący najczęściej z lasem czy znajdujący się w pobliżu jeziora - przeznaczony jest na wybiegi dla koni. Zwartość zabudowy to zaś czynnik zmienny, lecz nie wpływający w większym stopniu na odbiór formy założenia urbanistycznego czy funkcjonowanie ośrodków. Analizowane przykłady dowodzą, że obecność tych zwierząt jako szczególnie charakterystycznych i często spotykanych w mazurskim krajobrazie 
przyczynia się do rozpowszechniania specjalnego rodzaju turystyki konnej, ukierunkowanej właśnie na regionalizm, ale też do czynnej ochrony przyrody na Warmii i Mazurach. Ma to związek nie tylko z przedłużeniem gatunku, zamieszkującego opisywane tereny od wieków, ale także z występowaniem wyjątkowo dużej w skali kraju liczby stref natury prawnie chronionej. Obecność tak wielu stadnin koni (ponad stu) w województwie warmińsko-mazurskim stanowi bezcenny skarb, który świadczy o wartości regionu, poszanowaniu zastanych walorów krajobrazowych i chronionej natury, ale przede wszystkim sprzyja rozwojowi turystyki, promując to, co regionalne i zarazem najcenniejsze - przyrodę.

\section{BIBLIOGRAFIA}

Adamska, P., Łopatko-Pomianek, E. (2015). Szlak konny im. Marion Dönhoff. Pobrane z: https:// maskulinskie.bialystok.lasy.gov.pl/szlak-konny-im.-marion-donhoff\#.YJ1YPsBxdPZ (dostęp: 10.05.2021).

Bezmapy.pl. (2013). Popielno nad Jeziorem Śniardwy - ostoja koników polskich. Pobrane z: https://www.bezmapy.pl/przewodniki/polska/warmia-i-mazury/popielno-nad-jeziorem-sniardwy-ostoja-konikow-polskich-artykul623/ (dostęp: 10.03.2021).

Biczkowski, M., Brodowski, P. (2007). Uwarunkowania rozwoju oraz stan zagospodarowania agroturystycznego na obszarze dorzecza Drwęcy. Toruń: Uniwersytet Mikołaja Kopernika w Toruniu.

Dziennik.pl. (2017). Kraina Tysiqqca Jezior? Nieprawda! TEGO nie wiesz o Mazurach [10 PUNKTÓW]. Pobrane z: https://podroze.dziennik.pl/polska/artykuly/555028,gdzie-na-mazury-atrakcje-na-mazurach.html (dostęp: 26.02.2021).

Galopuje.pl. (2021). Warmińsko-Mazurskie - usługi, Jeździectwo, koine. Pobrane z: https:// galopuje.pl/warminsko-mazurskie-mapa/ (dostęp: 18.04.2021).

Gełdon, A. (2019). Szlak konny im. Marion Dönhoff". Pobrane z: https://spychowo.olsztyn. lasy.gov.pl/szlak-konny-im.-marion-donhoff\#.YGin89pxdPY (dostęp: 1.03.2021).

Gruchała, M. (2019). Konno przez Mazury szlakiem Marion Dönhoff. Pobrane z: https://www. trip4share.com/blog/szlak-marion-donhoff (dostęp: 26.02.2021).

Jaworski, Z., Jastrzębska, E., Górecka-Bruzda, A. (2018). Wypas koników polskich na terenach cennych przyrodniczo - kształtowanie krajobrazu i zachowanie bioróżnorodności. OlsztynJastrzębiec: Uniwersytet Warmińsko-Mazurski.

Jaworski, Z., Tomczyk-Wrona, I. (2009). Załq̨cznik nr 2 do Zarzq̨dzenia Nr 19/10 z dn. 16 kwietnia 2010 r. Program ochrony zasobów genetycznych koni rasy konik polski. Pobrane z: https:// docplayer.pl/19646253-Program-ochrony-zasobow-genetycznych-koni-rasy-konik-polski. html (dostęp: 18.04.2021).

Klaybor-Romańska, I. (b.r.). Ośrodek TREC. O nas. Pobrane z: http://www.stadninakurki. $\mathrm{pl} /$ ?lang=1\&main=139\&sub= (dostęp: 18.04.2021). 
Pajtuński Młyn. (b.r.). TREC PTTK. Pobrane z: http://pajtunskimlyn.pl/trec-3/ (dostęp: 18.04.2021).

PAN Popielno. (2021). Koniki polskie. Pobrane z: http://popielno.pl/koniki-polskie/ (dostęp: 01.03.2021).

Różański, P., Bojakowska, I., Kwecko, P., Tomassi Morawiec, H., Król, J. (2012). Objaśnienia do mapy geośrodowiskowej Polski 1:50 000 arkusz Olsztynek (213). Warszawa: Państwowy Instytut Geologiczny, Państwowy Instytut Badawczy.

Targońska, K. (2016). Ryby i konie jako najpopularniejsze zwierzęta w ofercie turystycznej Warmii i Mazur. W: S. Czachorowski, Ż. Kostyk (red.), Warmia i Mazury-nasze wspólne dobro cz. III (s. 121-127). Olsztyn: Centrum Badań nad Dziedzictwem Kulturowym i Przyrodniczym oraz Akademicki Klub Turystyczny Uniwersytetu Warmińsko-Mazurskiego w Olsztynie.

Uchwała nr XXXIV-305/2017 Rady Miejskiej w Olsztynku z dnia 29 czerwca 2017 r. w sprawie uchwalenia miejscowego planu zagospodarowania przestrzennego w obrębie geodezyjnym Świerkocin (Dz. Urz. woj. warm-maz 2017.3550).

Załącznik do Uchwały z 10 listopada 2016 r. Rady Miejskiej w Olsztynku, Miasto i Gmina Olsztynek Strategia Rozwoju Gminy Olsztynek na lata 2016-2020 z 2016 r., nr XXVII-225/2016. https://www.facebook.com/PajtunskiMlyn/photos/?ref=page_internal (dostęp: 10.05.2021). https://architektura.muratorplus.pl/polski-krajobraz/galeria.html?nr=12\&tp=0\&v=13452 (dostęp: 10.05.2021).

https://www.facebook.com/StadninaKoniKurkiTRECPTTK/photos/?ref=page_internal (dostęp: 10.05.2021). 